\title{
GMR
}

\section{Repellent effects of various cherry tomato accessions on the two-spotted spider mite Tetranychus urticae Koch (Acari: Tetranychidae)}

\author{
T. Lucini ${ }^{1}$, J.T.V. Resende ${ }^{2}$, J.R.F. Oliveira ${ }^{2}$, C.J. Scabeni ${ }^{2}$, A.R. Zeist ${ }^{2}$ and \\ N.C.V. Resende ${ }^{3}$ \\ 1'Departamento de Zoologia, Universidade Federal do Paraná, Curitiba, PR, Brasil \\ 2Departamento de Agronomia, Universidade Estadual do Centro Oeste do Paraná, \\ Guarapuava, PR, Brasil \\ ${ }^{3}$ Departamento de Agricultura, Universidade Federal de Lavras, Lavras, MG, Brasil \\ Corresponding author: J.T.V. Resende \\ E-mail: jresende@unicentro.br / jvresende@uol.com.br \\ Genet. Mol. Res. 15 (1): gmr.15017736 \\ Received September 28, 2015 \\ Accepted March 2, 2016 \\ Published March 24, 2016 \\ DOI http://dx.doi.org/10.4238/gmr.15017736
}

ABSTRACT. Several studies have been conducted on resistance sources to improve the genetic resistance of farm-grown tomatoes to arthropod pests, including phytophagous mites. In the present study, we evaluate the behavior of the two-spotted spider mite on different cherry tomato accessions to identify possible sources of resistance (repellent effect) to this pest. Sixty-four accessions of cherry tomatoes, Solanum lycopersicum var. cerasiforme (Dunal), were tested. In addition, a commercial cultivar of cherry tomato cv. Sweet Grape (susceptible pattern) and the wild tomato accession Solanum pennellii Correll LA-716 (multiple pest resistance) were evaluated as well. The distance traveled by mites on the leaflet surface over time varied largely among cherry tomato accessions. The wild genotype, S. pennellii LA-716, showed the smallest traveled distance on the leaflet 
surface (0.8 to $1.1 \mathrm{~mm}$ over time), and the variety cv. Sweet Grape was one of the genotypes with highest traveled distance (16.2 to $16.4 \mathrm{~mm}$ over time). The cherry tomato accessions 2298-42, RVTC-03, and 6889-53 showed a decrease in the traveled distance by mites over time, similar to that as observed in the wild tomato accession LA716. These accessions showed mite repellence levels similar to those of the wild genotype and may, therefore, be good candidates for breeding programs dealing with resistance to mites.

Key words: S. lycopersicum var. cerasiforme; Resistance; Repellence test; Behavior

\section{INTRODUCTION}

Tomato crops are often attacked by arthropod pests, such as the two-spotted spider mite Tetranychus urticae Koch (Acari: Tetranychidae). These mites mostly attack plants because the conditions are favorable for their development (Boom et al., 2003; Maluf et al., 2007). The control of arthropods pests, including spider mites, in tomato crops is usually performed using chemical pesticides. A more environmentally friendly solution would be, however, the development of resistant cultivars via breeding programs. Thus, resistance sources mainly found among wild tomato species, such as Solanum pennellii Correll and Solanum habrochaites S. Knapp and D.M. Spooner (Maluf et al., 2001, 2010; Resende et al., 2008), must be identified.

The resistance features of wild tomatoes have often been associated with the production and excretion of allelochemicals by glandular trichomes present in stems, fruits and leaves. Acylsugar is the main allelochemical produced by $S$. pennellii, whereas $S$. habrochaites produces two allelochemicals, 2-tridecanone and zingiberene (Maluf et al., 2001; Azevedo et al., 2003; Simmons and Gurr, 2005; Lucini et al., 2015). However, other tomato genotypes may also be resistant to pests, such as the cultivated variety Solanum lycopersicon var. cerasiforme (Dunal), commonly known as cherry tomato. This variety is the wild ancestor of farm-grown tomatoes (Peralta and Spooner, 2001), and its use in breeding programs has many advantages compared to wild tomato species (cherry tomatoes produce non-pubescent red fruits and are edible). Due to the genetic similarity between cherry tomatoes and wild tomatoes, the use of cherry tomatoes in breeding programs for pest resistance may, therefore, be advantageous. However, this potential has not been investigated in S. lycopersicon var. cerasiforme, to date (Sánchez-Peña et al., 2006). Therefore, the aim of this study was to evaluate the repellent effect of different cherry tomato accessions on the two-spotted spider mite.

\section{MATERIAL AND METHODS}

Spider mites, T. urticae, were obtained from infested bean plants, Phaseolus vulgaris L., grown in an experimental area at the Universidade Estadual do Centro-Oeste (Guarapuava, Brazil). Mites were reared on jack bean plants, Canavalia ensiformis (L.) D.C., under controlled conditions $\left(25^{\circ} \pm 2^{\circ} \mathrm{C}, 70 \pm 10 \%\right.$ relative humidity, and $12 \mathrm{~h}$ light: $12 \mathrm{~h}$ dark photoperiod). Cherry tomato accessions used in repellence tests had a natural occurrence and were collected in several places in Brazil (total of 64 accessions). In addition, the resistance pattern of the wild tomato 
accession S. pennellii LA-716 (resistance source to arthropod pests) and the susceptibility pattern of the cherry tomato variety S. lycopersicum cv. Sweet Grape (Sakata Seed ${ }^{\circledR}$ ) were evaluated.

To evaluate the resistance level (repellence) of the various tomato genotypes to $T$. urticae, the bioassay proposed by Weston and Snyder (1990) was used. For this, fully expanded leaflets (replications) with similar sizes were sampled from the upper third portion of 40-day-old plants of each tomato genotype tested. Sixty-seven tomato genotypes (treatments) with three replications each were tested.

Sampled leaflets were randomly nailed with the abaxial side up on A4 sheets of printing paper placed on polystyrene sheets, using a metallic thumbtack (diameter $10 \mathrm{~mm}$ ). Ten adult $T$. urticae females were placed on each thumbtack and the distance traveled by the mites on the leaf surface was measured 20, 40, and 60 min after mites were released (Weston and Snyder, 1990). Mites that stayed on the thumbtack were considered to have covered a distance equal to zero, whereas mites that went further than the limit of the leaflet were given a traveling distance equal to the distance covered by the mite found further away from the thumbtack. This bioassay is based on the principle that lower distances traveled by mites indicate higher levels of mite repellence. Data were analyzed using analysis of variance (ANOVA) and means were compared using the ScottKnott test $(P<0.05)$ in the $R$ program (version 3.1.2).

\section{RESULTS AND DISCUSSION}

Results showed a large variability among cherry tomato accessions. Overall, significant differences in repellence level were found between accessions in the different time periods $(20$, 40 , and $60 \mathrm{~min})(P<0.001)$. The resistant wild genotype $S$. pennellii LA-716 presented the lowest traveled distance on the leaflet surface (ranging from 0.8 to $1.1 \mathrm{~mm}$ over time) among all genotypes evaluated (Table 1). On the other hand, the susceptible variety cv. Sweet Grape was one of the genotypes with the highest traveled distance (ranging from 16.2 to $16.4 \mathrm{~mm}$ ). Similarly, SánchezPeña et al. (2006) have observed that cultivated tomatoes had the highest incidence of whiteflies (Bemisia spp Genn.), whereas the wild genotype S. habrochaites accession C-360 had the lowest.

Table 1. Average distances $(\mathrm{mm})$ traveled by Tetranychus urticae on the abaxial leaflet surface of different cherry tomato accessions during 20, 40, and 60 min after mite release.

\begin{tabular}{l|c|c|c}
\hline \multirow{2}{*}{ Accession } & \multicolumn{3}{|c}{ Travelled distance (mm) by mite onto surface leaflet after } \\
\cline { 2 - 4 } & $20 \mathrm{~min}$ & $40 \mathrm{~min}$ & $60 \mathrm{~min}$ \\
\hline S. pennellii & $1.1^{\mathrm{a}}$ & $0.8^{\mathrm{a}}$ & $0.8^{\mathrm{a}}$ \\
\hline RVTC-14 & $4.3^{\mathrm{a}}$ & $9.2^{\mathrm{a}}$ & $11.7^{\mathrm{b}}$ \\
\hline $2212-47$ & $4.9^{\mathrm{a}}$ & $7.6^{\mathrm{a}}$ & $10.5^{\mathrm{b}}$ \\
\hline RVTC-20 & $5.1^{\mathrm{a}}$ & $7.4^{\mathrm{a}}$ & $9.9^{\mathrm{b}}$ \\
\hline $0988-49$ & $5.6^{\mathrm{a}}$ & $7.6^{\mathrm{a}}$ & $9.9^{\mathrm{b}}$ \\
\hline RVTC-36 & $6.0^{\mathrm{a}}$ & $9.7^{\mathrm{a}}$ & $9.9^{\mathrm{b}}$ \\
\hline RVTC-30 & $6.1^{\mathrm{a}}$ & $9.7^{\mathrm{a}}$ & $13.0^{\mathrm{b}}$ \\
\hline RVTC-64 & $6.5^{\mathrm{a}}$ & $11.5^{\mathrm{a}}$ & $10.1^{\mathrm{b}}$ \\
\hline $2298-42$ & $6.6^{\mathrm{a}}$ & $7.1^{\mathrm{a}}$ & $7.3^{\mathrm{a}}$ \\
\hline RVTC-35 & $6.9^{\mathrm{a}}$ & $9.1^{\mathrm{a}}$ & $9.7^{\mathrm{b}}$ \\
\hline RVTC-03 & $7.2^{\mathrm{a}}$ & $6.7^{\mathrm{a}}$ & $6.6^{\mathrm{a}}$ \\
\hline
\end{tabular}

Continued on next page 
T. Lucini et al.

\begin{tabular}{|c|c|c|c|}
\hline \multirow[t]{2}{*}{ Accession } & \multicolumn{3}{|c|}{ Travelled distance $(\mathrm{mm})$ by mite onto surface leaflet after } \\
\hline & $20 \mathrm{~min}$ & $40 \mathrm{~min}$ & $60 \mathrm{~min}$ \\
\hline RVTC-63 & $7.5^{\mathrm{a}}$ & $10.7^{\mathrm{a}}$ & $11.2^{\mathrm{b}}$ \\
\hline RVTC-01 & $7.9^{\mathrm{a}}$ & $12.0^{\mathrm{a}}$ & $11.8^{\mathrm{b}}$ \\
\hline RVTC-37 & $8.0^{\mathrm{a}}$ & $8.4^{\mathrm{a}}$ & $11.4^{\mathrm{b}}$ \\
\hline RVTC-31 & $8.0^{\mathrm{a}}$ & $12.4^{\mathrm{a}}$ & $13.5^{\mathrm{b}}$ \\
\hline RVTC-22 & $8.0^{\mathrm{a}}$ & $12.4^{\mathrm{a}}$ & $14.7^{\mathrm{c}}$ \\
\hline $6889-53$ & $8.2^{\mathrm{a}}$ & $6.9^{\mathrm{a}}$ & $6.0^{\mathrm{a}}$ \\
\hline RVTC-09 & $8.4^{\mathrm{a}}$ & $11.4^{\mathrm{a}}$ & $16.6^{\mathrm{c}}$ \\
\hline RVTC-13 & $8.5^{\mathrm{a}}$ & $13.0^{\mathrm{b}}$ & $14.6^{\mathrm{c}}$ \\
\hline IAC-415 -68 & $9.0^{\mathrm{a}}$ & $10.1^{\mathrm{a}}$ & $11.5^{\mathrm{b}}$ \\
\hline RVTC-27 & $9.0^{\mathrm{a}}$ & $11.7^{\mathrm{a}}$ & $11.6^{\mathrm{b}}$ \\
\hline $2318-44$ & $9.1^{\mathrm{a}}$ & $11.7^{\mathrm{a}}$ & $11.8^{\mathrm{b}}$ \\
\hline RVTC-34 & $9.1^{\mathrm{a}}$ & $12.2^{\mathrm{a}}$ & $11.5^{\mathrm{b}}$ \\
\hline RVTC-41 & $9.2^{\mathrm{a}}$ & $10.6^{\mathrm{a}}$ & $10.8^{\mathrm{b}}$ \\
\hline $0489-60$ & $9.4^{\mathrm{a}}$ & $13.6^{\mathrm{b}}$ & $14.6^{\mathrm{c}}$ \\
\hline $1254-50$ & $9.4^{\mathrm{a}}$ & $11.5^{\mathrm{a}}$ & $12.1^{\mathrm{b}}$ \\
\hline RVTC-26 & $9.6^{\mathrm{a}}$ & $10.3^{\mathrm{a}}$ & $13.3^{\mathrm{b}}$ \\
\hline RVTC-21 & $9.6^{\mathrm{a}}$ & $13.9^{\mathrm{b}}$ & $14.1^{\mathrm{c}}$ \\
\hline RVTC-16 & $9.6^{\mathrm{a}}$ & $15.9^{\mathrm{b}}$ & $19.5^{\mathrm{c}}$ \\
\hline RVTC-12 & $9.7^{\mathrm{a}}$ & $11.8^{\mathrm{a}}$ & $11.7^{\mathrm{b}}$ \\
\hline RVTC-39 & $9.7^{\mathrm{a}}$ & $12.3^{\mathrm{a}}$ & $15.9^{\mathrm{c}}$ \\
\hline RVTC-61 & $10.0^{\mathrm{a}}$ & $15.2^{\mathrm{b}}$ & $14.3^{\mathrm{c}}$ \\
\hline $4346-56$ & $10.1^{\mathrm{b}}$ & $11.6^{\mathrm{a}}$ & $9.8^{\mathrm{b}}$ \\
\hline IAC-1498-70 & $10.2^{\mathrm{b}}$ & $12.7^{\mathrm{b}}$ & $12.8^{\mathrm{b}}$ \\
\hline RVTC-08 & $10.3^{b}$ & $17.3^{b}$ & $17.8^{\mathrm{c}}$ \\
\hline RVTC-05 & $10.4^{\mathrm{b}}$ & $13.8^{\mathrm{b}}$ & $15.0^{\mathrm{c}}$ \\
\hline RVTC-04 & $10.6^{\mathrm{b}}$ & $13.6^{\mathrm{b}}$ & $16.5^{\mathrm{c}}$ \\
\hline RVTC-18 & $10.6^{\mathrm{b}}$ & $13.8^{\mathrm{b}}$ & $16.3^{\mathrm{c}}$ \\
\hline RVTC-32 & $10.7^{b}$ & $11.1^{\mathrm{a}}$ & $10.8^{\mathrm{b}}$ \\
\hline RVTC-15 & $10.7^{b}$ & $12.9^{\mathrm{b}}$ & $14.9^{\mathrm{c}}$ \\
\hline RVTC-29 & $10.7^{b}$ & $12.9^{\mathrm{b}}$ & $14.9^{\mathrm{c}}$ \\
\hline RVTC-72 & $11.3^{\mathrm{b}}$ & $13.4^{\mathrm{b}}$ & $12.8^{\mathrm{b}}$ \\
\hline RVTC-02 & $11.4^{\mathrm{b}}$ & $10.5^{\mathrm{a}}$ & $14.1^{\mathrm{c}}$ \\
\hline RVTC-23 & $11.4^{\mathrm{b}}$ & $15.8^{\mathrm{b}}$ & $18.2^{\mathrm{c}}$ \\
\hline RVTC-17 & $11.5^{\mathrm{b}}$ & $20.3^{\mathrm{b}}$ & $18.9^{\mathrm{c}}$ \\
\hline $6878-52$ & $11.5^{\mathrm{b}}$ & $13.9^{\mathrm{b}}$ & $13.8^{\mathrm{c}}$ \\
\hline $4474-54$ & $11.6^{\mathrm{b}}$ & $12.2^{\mathrm{a}}$ & $14.3^{\mathrm{c}}$ \\
\hline RVTC-07 & $11.8^{\mathrm{b}}$ & $14.9^{\mathrm{b}}$ & $17.2^{\mathrm{c}}$ \\
\hline $0224-57$ & $11.8^{\mathrm{b}}$ & $15.7^{\mathrm{b}}$ & $14.9^{\mathrm{c}}$ \\
\hline RVTC-11 & $11.9^{\mathrm{b}}$ & $13.4^{\mathrm{b}}$ & $12.9^{\mathrm{b}}$ \\
\hline RVTC-25 & $12.2^{\mathrm{b}}$ & $14.0^{\mathrm{b}}$ & $15.5^{\mathrm{c}}$ \\
\hline $1258-51$ & $12.5^{\mathrm{b}}$ & $13.7^{\mathrm{b}}$ & $17.8^{\mathrm{c}}$ \\
\hline IAC-404-66 & $12.7^{b}$ & $12.0^{\mathrm{a}}$ & $12.0^{\mathrm{b}}$ \\
\hline RVTC-40 & $12.9^{\mathrm{b}}$ & $12.3^{\mathrm{a}}$ & $13.5^{\mathrm{c}}$ \\
\hline
\end{tabular}




\begin{tabular}{|c|c|c|c|}
\hline \multirow[t]{2}{*}{ Accession } & \multicolumn{3}{|c|}{ Travelled distance $(\mathrm{mm})$ by mite onto surface leaflet after } \\
\hline & $20 \mathrm{~min}$ & $40 \mathrm{~min}$ & $60 \mathrm{~min}$ \\
\hline RVTC-38 & $13.0^{\mathrm{b}}$ & $13.5^{\mathrm{b}}$ & $13.0^{\mathrm{b}}$ \\
\hline RVTC-19 & $13.1^{\mathrm{b}}$ & $15.6^{\mathrm{b}}$ & $18.9^{\mathrm{c}}$ \\
\hline IAC-1622-71 & $13.3^{\mathrm{b}}$ & $17.4^{\mathrm{b}}$ & $19.6^{\mathrm{c}}$ \\
\hline RVTC-62 & $13.5^{\mathrm{b}}$ & $11.4^{\mathrm{a}}$ & $13.1^{\mathrm{b}}$ \\
\hline RVTC-06 & $13.6^{\mathrm{b}}$ & $17.3^{\mathrm{b}}$ & $20.8^{\mathrm{c}}$ \\
\hline RVTC-24 & $13.6^{\mathrm{b}}$ & $15.0^{\mathrm{b}}$ & $15.0^{\mathrm{c}}$ \\
\hline RVTC-33 & $13.7^{\mathrm{b}}$ & $12.8^{\mathrm{b}}$ & $16.2^{\mathrm{c}}$ \\
\hline IAC-420-69 & $15.3^{\mathrm{b}}$ & $17.5^{\mathrm{b}}$ & $15.3^{\mathrm{c}}$ \\
\hline RVTC-10 & $15.4^{\mathrm{b}}$ & $16.0^{\mathrm{b}}$ & $17.6^{\mathrm{c}}$ \\
\hline IAC-392-65 & $15.4^{\mathrm{b}}$ & $18.6^{\mathrm{b}}$ & $19.9^{\mathrm{c}}$ \\
\hline 2091-46 & $16.1^{\mathrm{b}}$ & $17.0^{\mathrm{b}}$ & $18.3^{\mathrm{c}}$ \\
\hline Sweet grape & $16.2^{\mathrm{b}}$ & $16.4^{\mathrm{b}}$ & $16.4^{\mathrm{c}}$ \\
\hline $\mathrm{F}$ & $1.9^{* * *}$ & $2.7^{* * *}$ & $3.2 * * *$ \\
\hline
\end{tabular}

Means followed by the same lowercase letter within a column do not differ according to the Scott-Knott test $(P<0.05)$. ${ }^{* * *}$ Significant at $\mathrm{P}<0.001$ according to the $\mathrm{F}$-test.

Moreover, cherry tomato accessions showed an intermediate value of incidence. In the first 20 and $40 \mathrm{~min}$, the distance traveled by mites in several cherry tomato accessions did not statistically differ from the distance traveled on the wild genotype. However, after 60 min only three cherry accessions did not differ from wild tomatoes: RVTC-03, 2298-42, and 6889-53 (traveled distance ranged from 6.0 to $7.3 \mathrm{~mm}$ after $60 \mathrm{~min}$ ).

The resistance presented by the wild genotype $S$. pennellii LA-716 has been associated with the production and release of acylsugar (an allelochemical) by glandular trichomes, which are located on the plant surface. This allelochemical has been found to be responsible for the resistance to several arthropod pests, including tetranychid mites (Resende et al., 2002; Maluf et al., 2007; Alba et al., 2009; Baier et al., 2015; Lucini et al., 2015).

Sobreira et al. (2009) have reported the occurrence of large genetic variability among cherry tomato accessions. One of these accessions showed a significant resistance level to the tomato pinworm, Tuta absoluta (Meyrick). Moreover, Sánchez-Peña et al. (2006) have found significant differences among wild populations of cherry tomatoes at the mean level of whitefly incidence when compared to the wild genotype and the cultivated variety. In addition, the trichome density on the leaflet surface of cherry tomato accessions was, in general, high. However, the density of glandular trichomes was lower than in wild accessions, in which glandular trichomes were abundant. Furthermore, these authors found a negative relationship between whitefly incidence and leaflet trichome density. This indicates that trichomes may constitute an important factor in $S$. lycopersicum var. cerasiforme resistance to pests.

Cherry tomato accessions have several traits in common with farm-grown tomatoes. Thus, the genotypes 2298-42, RVTC-03, and 6889-53, that have shown repellence levels similar to the resistant genotype LA 716, could be used in breeding programs dealing with resistance to mites. However, it is necessary first to find out which factor is responsible for repellency. Factors such as cuticle thickness, allelochemical production, and/or density and type of leaflet trichomes (Maluf et al., 2007) could be responsible for the repellent effect of the above genotypes. 


\section{Conflicts of interest}

The authors declare no conflict of interest.

\section{ACKNOWLEDGMENTS}

We thank CAPES (Ministry of Education, Brazil) for the scholarships to T. Lucini and J.R.F. Oliveira. We also thank Dr. Arlete Tavares de Melo from IAC and Dr. Derly José Henriques da Silva from UFV for providing seeds of some cherry tomato accessions.

\section{REFERENCES}

Alba JM, Montserrat M and Fernández-Muñoz R (2009). Resistance to the two-spotted spider mite (Tetranychus urticae) by acylsucroses of wild tomato (Solanum pimpinellifolium) trichomes studied in a recombinant inbred line population. Exp. Appl. Acarol. 47: 35-47. PubMed http://dx.doi.org/10.1007/s10493-008-9192-4

Azevedo SM, Faria MV, Maluf WR, Oliveira ACB, et al. (2003). Zingiberene-mediated resistance to the South American tomato pinworm derived from Lycopersicon hirsutum var. hirsutum. Euphytica 134: 347-351. http://dx.doi.org/10.1023/ B:EUPH.0000005007.14924.d2

Baier JE, Resende JTV, Faria MV, Schwarz K, et al. (2015). Indirect selection of industrial tomato genotypes that are resistant to spider mites (Tetranychus urticae). Genet. Mol. Res. 14: 244-252. PubMed http://dx.doi.org/10.4238/2015.January.16.8

Boom CEM, Beek TA and Dicke M (2003). Differences among plant species in acceptance by the spider mite Tetranychus urticae Koch. J. Appl. Entomol. 127: 177-183. http://dx.doi.org/10.1046/j.1439-0418.2003.00726.x

Lucini T, Faria MV, Rohde C, Resende JTV, et al. (2015). Acylsugar and the role of trichomes in tomato genotypes resistance to Tetranychus urticae. Arth.-. Plant Int. 9: 45-53.

Maluf WR, Campos GA and Cardoso MG (2001). Relationships between trichome types and spider mite (Tetranychus evansi) repellence in tomatoes with respect to foliar zingiberene contents. Euphytica 121: 73-80. http://dx.doi. org/10.1023/A:1012067505361

Maluf WR, Inoue IF, Ferreira RPD, Gomes LAA, et al. (2007). Higher glandular trichome density in tomato leaflets and repellence to spider mites. Pesquisa Agropecu. Bras. 42: 1227-1235. http://dx.doi.org/10.1590/S0100-204X2007000900003

Maluf WR, Maciel GM, Gomes LAA, Cardoso MG, et al. (2010). Broad-spectrum arthropod resistance in hybrids between highand low-acylsugar tomato lines. Crop Sci. 50: 439-450. http://dx.doi.org/10.2135/cropsci2009.01.0045

Peralta IE and Spooner DM (2001). Granule-bound starch synthase (GBSSI) gene phylogeny of wild tomatoes (Solanum L. section Lycopersicon [Mill.] Wettst. subsection Lycopersicon). Am. J. Bot. 88: 1888-1902. PubMed http://dx.doi. org/10.2307/3558365

Resende JTV, Maluf WR, Cardoso Md, Nelson DL, et al. (2002). Inheritance of acylsugar contents in tomatoes derived from an interspecific cross with the wild tomato Lycopersicon pennellii and their effect on spider mite repellence. Genet. Mol. Res. 1: 106-116. PubMed

Resende JTV, Maluf WR, Cardoso MG, Faria MV, et al. (2008). Resistance of tomato genotypes with high level of acylsugars to Tetranychus evansi Baker \& Pritchard. Sci. Agric. 65: 31-35. http://dx.doi.org/10.1590/S0103-90162008000100005

Sánchez-Peña P, Oyama K, Núñez-Farfán J, Fornoni J, et al. (2006). Sources of resistance to whitefly (Bemisia spp.) in wild populations of Solanum lycopersicon var. cerasiforme (Dunal) Spooner G.J. Anderson et R.K. Jansen in Northwestern Mexico. Genet. Resour. Crop Evol. 53: 711-719. http://dx.doi.org/10.1007/s10722-004-3943-9

Simmons AT and Gurr GM (2005). Trichomes of Lycopersicon species and their hybrids: effects on pests and natural enemies. Agric. For. Entomol. 7: 265-276. http://dx.doi.org/10.1111/j.1461-9555.2005.00271.x

Sobreira FM, Sobreira FM, Andrade GS, Almeida GD, et al. (2009). Sources of resistance to tomato leafminer in cherry tomato. Sci. Agric. 10: 327-330.

Weston PA and Snyder JC (1990). Thumbtack bioassay: a quick method of measuring plant resistance to twospotted spider mites (Acari: Tetranychidae). J. Econ. Entomol. 83: 500-504. http://dx.doi.org/10.1093/jee/83.2.500 